\title{
The Weakness of Populism in Spain
}

\author{
Astrid Barrio \\ UNIVERSITAT DE VALÈNCIA \\ astrid.barriofuuv.es
}

Received: 22/05/2019

Accepted: 09/03/2020

\begin{abstract}
This paper analyses why Populism has failed to take root in Spain despite a 'soil' that has favoured its seeding and growth elsewhere. At first sight, Spain seems to provide the conditions in which Populism can thrive: a deep economic crisis (which began with the financial meltdown in 2008) and a succession of corruption scandals affecting all the main political parties. Even so, Populism has failed to gain a hold in Spain. The traditional Far Right is very weak, and new parties such as Podemos and Ciudadanos cannot be considered Populist. While Vox displays all the features of a radical right-wing party, it is one from which Populism is absent. We argue that the lack of Populism in Spain can mainly be explained by the highly fractured nature of the country's politics, with left-right and national fault lines shaping how political competition plays out in the nation.
\end{abstract}

Keywords: populism, Far Right, Radical Right, Podemos, Ciudadanos, Vox.

Corresponding author: Astrid Barrio López. Departamento de Derecho Constitucional, Ciencia Política y de la Administración. Facultat de Dret. Avda. dels Tarongers s/n, 46022 València (Spain)

Suggested citation: Barrio, A. (2020). The Weakness of Populism in Spain. Debats. Journal on Culture, Power and Society, 5 , 197-209. DOI: http://doi.org/10.28939/iam.debats-en.2020-11

\section{INTRODUCTION}

One of the most striking recent political happenings worldwide has been the emergence of Populism something from with few advanced democracies have escaped unscathed. Indeed, Populism has spread to the point where some scholars have even gone so far as say that it is now the norm in Western democracies rather than the exception (Marzouki, McDonnel and Rey, 2016).

This paper shows that Spain is indeed an exception even though many of the conditions needed for the emergence and growth of Populism can be found in the country (Barrio, 2017a). The global financial crisis hit Spain in 2008 and this was followed six years later in 2014 by a political crisis stemming from wholesale corruption in Spain's main parties. These crises created the conditions for the emergence of new political parties - such as Podemos and Vox - and the expansion of Ciudadanos [Ciutadans] from Catalonia to Spain as a whole. Yet at root, none of these parties can be called 'Populist'. The hurdles to Populism in Spain are the predominance of a Left-Right political division, and 'The National Question' [Spain as a centralised, unitary State, or as an assemblage of nations]. The two factors articulate politics in Spain. 
The paper comprises four sections. The first defines Populism and sets out the conditions favouring its birth and growth. The second gives the reasons for the Far Right's limited presence in Spain up until Vox came on the scene. The third explains why Ciudadanos and Podemos - two recently-founded parties - cannot be considered Populist parties. The fourth and final section sets out the reasons why Vox is a Far-Right party but not a Populist one.

\section{DEFINITION, EMERGENCE AND CONSOLIDATION}

The word Populism is now on everyone's lips and has clearly pejorative connotations. It is used to demonise parties and leaders who seldom consider themselves as such. Furthermore, it has been used to refer to a bewilderingly wide variety of movements and parties in many places and at many times. It is little wonder then that coming up with a satisfactory definition of Populism is no easy task (Canovan, 1982). That said, this has not stopped academics trying to come up with a single unifying theory.

Populism has been approached from many angles and disciplines. They all share the premise that Populism takes a dualistic approach as a result of placing 'The People' (characterised as naturally virtuous) in opposition to the governing elite (corrupt by definition). Going beyond this minimum common denominator, the debate is grounded on the distinction proposed by Moffit and Torney (2014), in which Populism is considered an ideology - a logic if you will — which leads to a kind of discourse and communication style. Some go even further and suggest that it is a strategy and/or an organisational form.

Populism can be seen as an ideology insofar as it gives meaning to a consistent set of ideas on how society should be organised and how power should be wielded. Nevertheless, rather than an ideology in the strict sense, Populism is usually taken to be a thin ideology (Stanley, 2008) that needs to be mixed with other ideologies (whether thick or thin ones), such as Nationalism. By contrast, others see Populism as a logical system, and instead focus on the phenomenon's ontological dimension. The latter approach is the one taken by Laclau (2005), who considers Populism as a logical system for structuring political life and for framing the struggle for hegemony. Thus, a movement, party, or leader should not be labelled Populist merely on the basis of its policies and ideology but rather because the leader/party articulates them within a given logical system. The idea of Populism as a discursive pattern or as a communication style puts the spotlight on the notion of 'The People' (as the fount of all virtue) cruelly betrayed by corrupt elites who must be overthrown for the good of society. This is Populism's leitmotiv and its main argument. That is why another approach sees Populism as a strategy and/or a form of organisation in which charismatic leaders seek direct, immediate, non-institutional support through their followers. With a view to overcoming the limitations of these different approaches, Moffit and Torney (2014) argue that Populism must be seen first and foremost as a political style characterised by an appeal to The People as the bearers of sovereignty, and by opposition to a corrupt elite. Another ingredient of Populism is the idea that there is a national emergency, crisis, or threat that requires a tough 'no-nonsense' response.

There are many ways of approaching Populism. Among them, Mudde's definition (2004: 543) of Populism as a thin ideology is one that has gained broad acceptance. According to Mudde, Populism is "an ideology that sees society as split into two homogeneous, opposing groups - 'the good guys' (The People) and 'the bad guys' (the corrupt elite). Populist parties argue that politics should be an expression of The People's Will". This definition covers much of the various approaches to the issue and, as Kriesi and Pappas (2015) noted, there are four key elements. These are: (1) acceptance that there are two homogeneous groups - The People and The Elite; (2) the interests of the two groups are diametrically opposed; (3) The People is sovereign; (4) a perspective in which The People is put in a positive light while The Elite is vilified.

Pappas (2014) and Kriesi and Pappas (2015) add that Populism is an illiberal interpretation of democracy 
(Zakaria, 1997). That is because Populism is based on a literal interpretation of 'government by the people' and eschews classic Liberal checks and balances in the political system. Second, Populism is hostile towards 'middle-men' and seeks a direct link between leaders and the masses, with the stress on grass-roots democracy. Last but not least, it stresses the idea of a monolithic 'Will of The People' which leaves no room for pluralism. Yet this monolithic interpretation not only creates antagonism towards the elites but also towards other groups that are not seen as belonging to 'The People'. This is where the issue of identity arises, whether in national, cultural or religious terms and linked with a 'nativist' outlook. This is the common approach taken by Populist parties belonging to the Far Right in Europe. They argue that The People risks losing its identity in the face of globalisation, immigration, and multi-culturalism (Marzouki, McDonnel and Rey, 2016). These parties see immigrants in general and Muslims in particular as posing a threat to The People's values and religious traditions, although in many cases the culture they consider to be traditional is most often one based on laicism. By contrast, Left-Wing parties lack this identity element and lean towards laicism, lack of faith, and multiculturalism.

The absence of a general theory of Populism has not hindered broad consensus on what the reasons are for Populism's recent emergence and growth — especially in The West. Most of the explanations are rooted in various dimensions of the 2008 Global Financial Crisis and its aftermath (Shambaugh, 2012). Taking this line, Populism is the result of the anger and frustration arising from the Global Financial Crisis (GFC) and the austerity policies that followed. However, it might also be a reaction to the perverse effects of globalisation in broad swathes of Western society. Here, some of those who have lost their jobs see mass immigration as a threat, while many Middle Class voters have seen their wages and prospects shrink, giving them a sense of relative privation (Eatwell and Goodwin, 2018). Populist leaders have seized upon this seething discontent and have sought to mobilise ordinary people against the political and economic elites whom they consider to blame for the present state of affairs. By contrast, Populism - argue its exponents - seeks to govern in the name of The People and is the answer to representing it politically. From this standpoint, the rise of Populism is also a political phenomenon (Roberts, 2015).

As a result, Populism is not just a reaction to economic problems and a view of globalisation as a threat but is rather a political issue that has been simmering for a long while, undermining traditional parties. The shrinking support for traditional parties can be seen in their falling membership rolls and waning share of the vote, as well as in greater volatility in voting patterns. All these things reveal political parties' woes, and as Mair (2013) has noted, all need to be dealt with at the same time. Parties find themselves both having to pander to the electorate's demands in opposition but act responsibly when they are in power. The combined impact of the economic and political crises thus explains the surge in Populism.

Nevertheless Populism is not homogeneous but rather is shaped by sundry factors. Some of these are of a cultural nature and are linked to each society's policies in this field (Norris and Inglehart, 2018). Others are institutional, such as the hurdles placed by each electoral system. Yet other factors are of a political kind such as the fault lines found in traditional politics and, with them, the degree to which parties and party systems are institutionalised. On this last point, one might expect that the persistence of classic political fault lines would hinder the emergence of Populism. Conversely, one would expect the weakening of those fault lines and low institutionalisation of parties and the systems to which they belong to foster Populism's emergence and growth. This paper argues that the electorate in Spain does not differ from that in other countries where Populism has taken root - especially its Right-Wing variant (Alonso and Rovira Kaltwasser, 2015). In those countries, the electoral system has not stopped new Populist parties making their mark and altering the party system, making it much more open-ended (Rodríguez-Teruel and Barrio, 2018). In Spain however, the country's strong political fault lines 
seem to be the main factor explaining why Populism has put down very shallow roots.

\section{THE LIMITED PRESENCE OF FAR-RIGHT POPULIST PARTIES}

After many years of fixed political fault lines and stability in the party system, the first Populist parties to shake up politics in Western Europe in the early 1980s were ones on the Far Right. This family of parties is characterised by its 'nativism', seen in its anti-immigration discourse, and its fierce opposition to multi-culturalism, globalisation, and EU integration (Mudde, 2007). Populism has been the political current that has waxed most in Europe since then but this is not the case in Spain, where political discontent and opposition to immigration is broadly on a par with those found in other European countries where Populist parties have sprung up.

Plataforma per Catalunya (PxC) meets all the criteria for being considered a Right-Wing Populist Party and was the first of its kind in Spain to win seats. The party was opposed to mass immigration, which it saw as a threat to both Catalan and Spanish identities and to traditional family values. It was highly critical when it came to crime and terrorism, arguing that natives should be given preference in assigning social benefits. Here, the party made efforts to overcome traditional political divisions. Under the leadership of Josep Anglada (who had a Far Right background), the party made a big impact on the media and was able to build a modern Populist discourse with strong local roots (Hernández-Carr, 2011). This strategy yielded modest results. PxC had a presence in Catalan municipalities with a high concentration of foreign immigrants but never won seats in either the Catalan Parliament or in the Spanish Parliament (Casals, 2011; HernándezCarr, 2012). The party was dissolved in February 2019 but continued its activity as a foundation, forming part of Vox.

The traditional Far Right linked to Francoism has also been very weak since Spain's transition from dictator- ship to democracy, obtaining scarcely any institutional representation. Only Fuerza Nueva in 1979 was able to pass the electoral threshold to win just one seat in Spain's Parliament. The seat was held by the party's leader Blas Piñar. Since then, this 'political family' has failed to gain a foothold in any tier of government in Spain (Casals, 1998). There are many reasons for this: inability to come up with an attractive discourse; its nostalgia for Spain's Fascist past; its dalliance with violence; strong internal rifts and lack of leadership; Spaniards' show an overwhelming preference for moderate political parties. Together, these factors explain why Spain's classic Far Right has been politically irrelevant since the restoration of democracy.

The failure of Far-Right parties (notwithstanding their potential electoral appeal) has been ascribed by Alonso and Rovira Kaltwasser (2015) to three political hurdles. The first of these is that Spain's electoral system makes it hard for small parties to break into the political scene. The second is that Spanish politics has two very strong fault lines: Left-Right, and Centre-Periphery. These fault lines are so marked that it is well-nigh impossible to come up with new lines of conflict, especially if they have an 'exclusivist' or 'nativist' component. That is why the few parties that have tried to exploit immigration or religion as political issues have had so little success at the local level, as PxC's case shows. PP's presence is the third factor explaining the absence of the Far-Right in Spain. PP Is Spain's main CentreRight party and it has long opted for a competition strategy that lets it fill the whole of the Right of the political spectrum, running from the Centre-Right to the Far-Right. Thus PP mobilises voters that might otherwise vote for Far-Right Populist parties.

Even so, Esteban and Martín (2017) have recently questioned these explanations. With regard to the electoral system, they argue that although it did not traditionally favour the entry of new parties, the advances made by Ciudadanos and Podemos during the 2014-2016 electoral cycle shed doubt on this argument. The system of parties was therefore not the result of the electoral system (the classic institutional explanation given by the Duvergerian matrix) but 
rather the result of political alignments reflecting rifts in society - which raise issues of a sociological nature. In relation to the structure of these political fault lines, it has been argued that in other countries where there is a split between the centre and the periphery (such as in Italy, Belgium, and The United Kingdom) Right-Wing Populist parties have been able to overcome the voting threshold to gain seats. They have done so by linking link immigration with the clash between centre and periphery, stressing worries about identity, recalling similar linkages seen in Spain (Pardos Prado, 2012). Finally, Esteban and Martín concluded that in some key respects, PP votes are no different from voters for Far Right Populist parties elsewhere in Europe, especially when it comes to their views on immigrants' religion and culture, and the 'threat' they pose to jobs. Nevertheless, they differ in the following respects: (1) their tendency to support the governing party; (2) they are less belligerent towards immigrants because many of the latter are of Hispanic origin, with whom they share cultural roots; (3) a more pro-EU outlook; (4) greater respect for Law and Order. Thus there are PP voters who might identify with Far Right supporters but that have remained hidden among the heterogeneous mass of the party's share of the electorate. The PP is a highly institutionalised party that has lacked Right-Wing rivals until recently. It has proved capable of attracting both potential Far-Right voters and moderate Right-Wing voters. However, the spell was broken when a host of corruption scandals undermined the PP government. The upshot was that PP lost power in 2018 after a successful 'No Confidence' motion in Spain's Congress. This put a new PSOE government (led by Pedro Sánchez) in the riding seat. From that point on, the Right began to fracture, with Ciudadanos and its competitive strategy being wrong-footed by the major electoral gains made by Vox.

\section{THE NEW PARTIES: PODEMOS AND CIUDADANOS}

The rise of new parties in Spain coincided with the waves of Populism identified by Casals (2013). The first wave spanned from 1989 to 2000 and was led by José María Ruiz-Mateos, who won two seats in the European Parliament in 1989, and by Jesús Gil, whose Grupo Independiente Liberal (GIL) won seats in several Andalusian municipalities, including that of Marbella. Gil was elected Mayor of Marbella, and as President of Ceuta (a small Spanish outpost and autonomous region in North Africa). As Álvarez Tardío (2017) noted, both Ruiz-Mateos and Gil were businessmen who went into politics. Their political pitch was that they would put a stop to the arbitrariness and corruption that had been inflicted on them by the two main parties. Both initiatives exploited the opportunities offered by multi-tier governance structures, with Gil focusing on local and regional government, and Ruiz-Mateos on the EU parliament. Yet both found that extending their reach to other tiers of government was no easy task. In the end, both of them failed to expand their respective political toeholds. The last exponent of this first Populist wave was another businessman, Mario Conde, who failed to win a seat in Spain's Parliament (Congreso de los Diputados) in 2000. The two major parties (PSOE and PP) were strong and had a finger in every institutional pie whether they were in government or out. Against them, the Populist parties (based as they were on a single person and with few roots in society) did not stand a chance and soon ran into the sand.

The second wave began in 2003 in Catalonia with the emergence of Plataforma por Cataluña and Candidatura d'Unitat Popular (CUP), the latter a regional LeftWing Party with a pro-Catalan independence agenda. Later on, more initiatives were launched to exploit the endless clashes between Catalonia and Spain, one such being Solidaritat Catalana. Yet neither Plataforma por Cataluña, nor Solidaritat had much success, only fleetingly holding seats in the Catalan Parliament (2010-2012). By contrast, CUP won its first seats in the Catalan Parliament in 2012. Since 2015, CUP has not only held seats in every legislature but has also played a key role in forming coalition governments. This helps explain the Populist drift taken by Catalan nationalism over the last few years (Barrio, Barberà, Rodríguez Teruel, 2018). It also reveals why both the party system and the national rift have become more 
important than the Left-Right rift (Rodríguez Teruel and Barrio, 2018).

The third wave of Populism began in 2008. As we noted earlier, from this year onwards, many of the factors giving wings to Populism were now to be found in Spain. These factors were: (1) a deep economic crisis fuelling mass unemployment (25\%-plus); (2) aggressive austerity measures by successive PSOE and PP governments involving deep cuts in social spending and a bail-out of much of Spain's banking sector; (3) a host of corruption scandals affecting the two main parties - especially PP, which had governed with an absolute majority since 2011. Statistics from Spain's CIS (sociological research centre) reveal that citizens' wrath at the political state of affairs was so great that from 2013 onwards, Spaniards considered politicians and their parties as the main source of corruption and of the economic problems plaguing the country. In this scenario, one might expect the emergence of Populist parties (whether Left or Right) in Spain given that this is what happened in other Western European nations. The slump and voters' loss of trust in politicians from the two main contenders opened the door to new parties (Medina and Correa, 2016; Cordero and Montero, 2015; Orriols and Cordero, 2016; Rodon and Hierro, 2016; Bosch and Durán, 2017). Even so, although all parties had picked up some Populist tricks, one cannot say that Populism had put down roots in Spain. As we shall see, the Left-Right split in Spanish politics and the 'nationalist' split stopped Populism from gaining a foothold.

Podemos came into being in 2014 and sought from the outset to impose a Populist approach of the kind meant by Ernesto Laclau (2005). It was the only Spanish party that defined itself as Populist, which is why various authors have treated it as such (Zarzalejos, 2017; Sanders et al., 2017; Solà and Rendueles, 2017; Ivaldi et. al., 2017). Podemos tried to overcome the Left-Right dialectic in Spanish politics - the biggest rift in the Spanish political system - and to replace it with the dualism of The People versus the elites (Rodríguez-Teruel, Barrio and Barberà, 2016; Barrio, Barberà, Rodríguez-Teruel, 2018). In keeping with the classic Populist scheme, Podemos sought to champion the rights of ordinary people against the interests of the elite, adopting the classic Italian concept of casta (caste) - an idea that spread like wildfire after being used on television by the party's leading lights, such as Pablo Iglesias. The concept underlying the party was strongly shaped by the work La Razón Populista by Laclau (2005), which raised the idea of the NationState as a construct to serve The People. Podemos' conception of the nation was based on three planks (Torreblanca, 2015: 139). The first was that the elites did not represent The People, expressed in the slogan "They do not speak for us", lifted from the 15-M movement. Here, Podemos positioned itself as that movement's heir. The second concerned sovereignty, which Podemos took in its traditional sense, referring to the State's autonomy from foreign influences - a clear allusion to supra-national bodies, especially The European Union which had shamelessly dictated Spanish economic policy since the outbreak of the financial crisis. The third plank drew on the same concept of the nation to guarantee social rights. Podemos' aim was to build on social and national planks to build a broad political platform capable of mobilising broad swathes of the electorate in the same way the 15-M movement had. Nevertheless, Podemos tripped over two hurdles to its political ambitions, both stemming from the old political fault lines found in Spain.

One of these hurdles was the Left-Right split and its historic importance in Spanish politics. The appearance of another new political party - Ciudadanos - considered by some to be the Right-Wing's version of Podemos (as the famous banker Josep Oliu put it) forced Podemos to politically position itself in the LeftRight battle. Later on, with a view to beating PSOE, it opted for a catch-all strategy which sought to put Podemos "at the centre of the political chessboard". That is why it became more Populist. Podemos can be considered a radical Left-Wing party if one takes Mudde and March's criteria (2005). It is radical because it rejects the socio-economic structure underlying contemporary Capitalism and its values and practices. Here, the party proposes alternative economic and power structures that imply radical wealth redistribu- 
tion from the haves to the have-nots. It is Left-Wing because of its commitment to collective economic and social rights. Nevertheless, its radicalism has waned over time, especially since its entry into the coalition government in January 2020.

Podemos' first election manifesto (for the 2014 European Elections) clearly expressed this radical LeftWing ethos. The programme was drawn up through open assemblies in which over 30,000 members took part, many of whom had been involved in the organisation of the $15 \mathrm{M}$ protests. This explains the adoption of maximalist positions on economic matters, such as retirement at sixty, the refusal to repay Spain's National Debt, a basic income for everyone, and nationalisation of Spain's key economic sectors - all measures that the party subsequently rejected as impractical. Later on, the party commissioned an economic programme from two renowned experts, Vicenç Navarro (Full Professor of Politics and Social Sciences at Universitat Pompeu Fabra - UPF) and Juan Torres (Full Professor of Economics at Universidad de Sevilla - US). This programme shifted the party into a social-democratic frame, giving it a better chance of fighting PSOE on equal terms. This move towards the Centre stopped Podemos following the path to political extinction taken by Izquierda Unida, a tiny party that was the heir of Spain's Communist Party. Later on, its alliance with PSOE from the 2016 General Election onwards strengthened its positioning in this part of the political spectrum. The move also helped consolidate Podemos' growth at the expense of the internally-riven PSOE. Even though Podemos and PSOE were competitors, the former supported the latter in 2018 in a Motion of No-Confidence against the then PP-led government. The motion was passed, and Pedro Sánchez - the PSOE's leader - became President. After the 2019 General Election, the two parties formed a coalition in which Podemos held one of the Vice-Presidencies (exercised by Pablo Iglesias), with the latter party being given four ministerial posts.

The second hurdle to Podemos' Populist ambitions stemmed from the political fault line between Spain's centre and periphery. As we noted earlier, Podemos' concept of nation was linked to the idea of democracy and sovereignty, understood in the classic sense. It thus referred to the State's autonomy and the social rights guaranteed thereby. Nevertheless, Spain's complexity as a Nation-State and the prospects for the party's spread and consolidation made it difficult to establish who: 'The People' was; the party sought to represent; the nation comprised. Podemos and its allies in various regions - including Catalonia - assumed that Spain was a State comprising several nations with diverse aspirations. This was a notion that sat ill with a dialectic based on 'The People against The Elites'. Accepting the principle of sundry demoi meant also taking it as read that each demos had its own demands and aspirations within a system of highly asymmetric relations. Podemos had also faced the challenge of adapting its Populism to the various national identities found within the Spanish State. The party had shown that it was not only willing to give practical recognition of Spain's pluri-national nature but also supported Catalonia's and The Basque Country's secessionist goals. This is why Podemos supported Catalonia's right to a legally-agreed referendum on the country's independence from Spain. That said, the party began to shift position as soon as it became a member of the coalition government. This re-positioning not only gave rise to strong internal tensions in the party but also clearly contradicted the party's Populist stance, putting it in an ambivalent position on the centreperiphery fault line.

Nevertheless, as Vallespín and Bascuñán (2017) note, these hurdles have not stopped Podemos from keeping some of its Populist features, which include: (1) simplification of the language used; (2) mistrust of parliamentary democracy; (3) the rhetoric based on The People as protagonist and with a clearly-defined antagonist; (4) new communication techniques based on emotive appeal and wrapped up in rationality.

Ciudadanos Is a party that sprang to life in 2006 as a response to the demand by some sectors that were unhappy with the way some Left-Wing parties had leapt on the nationalist bandwagon (Rodríguez Teruel and 
Barrio, 2016). Despite a short-lived alliance with the Europhobe Libertas party in the 2009 European Elections, Ciudadanos cannot be considered a Populist party even if the Zeitgeist has rubbed off on it - something that applies to many other European parties (Rooduijn et al., 2012). In this respect, Ciudadanos was one of the first parties in Spain (together with Unión Pueblo y Democracia - UPyD) to systematically denounce the established parties for their corruption. Here, one should note that this denunciation came well before the 2008 and 2014 crises. Indeed, UPyD even went so far as to accuse the two mainstream parties of running a kind of mutual protection racket. That is why Ciudadanos argued the need for a renewal of democracy. This discourse, although it arose in Catalonia and addressed a specific Catalan issue, allowed Ciudadanos to spread its wings to the rest of Spain from 2014 onwards (Barrio, 2017b, 2017c). The party, along with Podemos, was an exponent of a new style of politics. Without going so far as to take on the mantle of Populism's 'The People versus The Elite' dichotomy, Ciudadanos — like Podemos — sought to overcome the Left-Right fault line and break the old political mould. The party even stated that, like some Populist movements, it was neither Left-Wing nor Right-Wing. It then steadily repositioned itself to end up as a Centre-Right party. At its party congress held in February 2018, Ciudadanos (in keeping with its international membership of the Alliance of Liberals and Democrats for Europe) chose to remove references to Social Democracy in its credo and define itself strictly as a Liberal party. This, it hoped, would help it win more seats than PP following the fragmentation of the right of the political spectrum. At the same time, it upped the ante by vociferously attacking peripheral nationalisms, especially that in Catalonia, competing with PP and Vox in defending the unity of Spain. As some observers had foreseen, Ciudadanos shifted from being a middle-of-the-road party to become a Right-Wing version of Podemos. Its support for PP during the Motion of No Confidence and its subsequent refusal to govern as part of a coalition with PSOE after the April 2019 General Election put the seal on this change. Here, one should note that such a coalition with PSOE would have been viable in terms of commanding a parliamentary majority and perhaps even ideologically. This choice proved unpopular with the party's voters, with Ciudadanos nose-diving from 57 seats in the April 2019 General Election to just 10 seats in the November 2019 General Election.

\section{VOX; A RADICAL RIGHT-WING PARTY, NOT A POPULIST PARTY}

The birth of Vox, like that of Podemos and of Ciudadanos, came about as a result of the political opportunities opened up in 2014. It fielded candidates for the European Elections in that year. Unlike the other two Right-Wing parties, Vox obtained no seats in this or in any other European Parliament election. Yet it did win a few seats in the 2015 municipal elections. This situation persisted until 2018 and the Andalusian Regional Election, when Vox made its first breakthrough. The Andalusian election was important because it was the first one since the PP had lost the confidence of Spain's Congress. It was also the first election outside Catalonia after this region's illegal Independence Referendum held on the $1^{\text {st }}$ of October, followed by a Unilateral Declaration of Independence, which was then quashed by the application of Article 155 of the Spanish Constitution (involving a round-up of pro-independence Catalan politicians and a Central Government take-over of the Regional Government). From this moment on, given the threat to Spain's territorial integrity and a greatly weakened PP, Vox positioned itself as 'the country's saviour' and saw a surge in both electoral support and organisational capabilities (Barrio, 2019). Vox made an excellent showing in the Andalusian election. There, the party not only crossed the threshold needed to win seats but also became a vital piece in any coalition government. Vox also won seats in Spain's national parliament following the April 2019 General Election, getting no fewer than 24 deputies in Congress. The party also crossed the vote threshold in some 'autonomous communities' (self-governing regions) such as Madrid and Murcia, and in some municipalities such as Madrid. Vox also won three seats in the European Parliament. After the November 2019 elections, it won 57 seats, becoming Spain's third-strongest political force with $3,656,979$ votes. 
Vox is above all a Spanish nationalist party whose spectacular growth can be ascribed to the political fall-out from the Catalan crisis. Its gung-ho nationalism stems from concern over the unity of Spain and what it sees as the threat of Catalan nationalism. The party is highly critical of the decentralised political model ushered in by the 1978 Spanish Constitution, which created a 'State of Autonomies' [Estado de las Autonomias], which is to say a system where the regions enjoy a degree of self-government. Vox seeks to turn Spain into a unitary State that is administratively decentralised. The party recognises Spain's cultural, linguistic, and institutional diversity but stresses that Spanish (Castilian) must enjoy a hegemonic position throughout the length and breadth of the land. Vox's extreme defence of Spanish unity is shown by the fact that it has even gone so far as to hint it would outlaw independence parties (for instance, in Catalonia and The Basque Country). Although it does not say so explicitly, it seeks to introduce a militant model of democracy that falls outside the Spanish Constitution. Furthermore, it proposes a wide-reaching plan to disseminate and protect the national identity by fostering Spanish nationalism of the kind last seen under Franco's Fascist dictatorship.

The party's nationalism is accompanied by traditionalist, nativist, and xenophobic traits and it is hostile to what it terms gender ideology. Its traditionalism is patently clear in its defence of the traditional family as an institution that pre-dates the State. This is why Vox opposes abortion and sex changes. The party also lauds traditions such as bull-fighting and demands the closure of fundamentalist mosques. At the same time, it demands reciprocity in opening places of Christian worship and demands that Islam be excluded from the school curriculum. In addition, Vox advocates the creation of an aid agency for threatened Christian minorities abroad. The party links immigration strictly to the country's economic needs and is keen to encourage settlement by newcomers from Spanishspeaking Latin America. It also seeks to deport illegal immigrants and those who commit serious crimes. By the same token, Vox opposes giving illegal immigrants the chance to regularise their status or to receive public aid. Like Donald Trump's proposal to build a wall between The United States and Mexico, Vox would build a wall between Ceuta and Morocco, and between Melilla and Morocco, which it demands should be paid for by the Moroccan Government. Vox accuses Feminism (as do many other Right-Wing movements) of fostering a gender ideology and says that Feminist organisations should be banned. Given half a chance, the party would also scrap gender quotas and abolish Spain's Gender Violence Act on the grounds that it discriminates against men. Vox would replace the legislation by a 'Family Violence Act' in which all family members would be treated the same.

Security is another Vox hobby-horse. In this field, it would toughen sentencing and prison conditions, and would scrap Spain's membership of The Schengen Area until the EU gave a binding undertaking that nobody would be given safe haven from Spanish justice - a clear allusion to the many Catalan politicians who fled abroad seeking asylum. The party also defends life imprisonment of former members of the ETA terrorist organisation, and barring those who have supported ETA's political demands from public office. Among Vox's more colourful proposals is giving citizens the right to bear arms, defend their homes by force, and even to decorate citizens who injure or kill a criminal entering their homes and in self-defence.

On the other hand, Vox supports the idea of democratic renewal and proposes reform of the electoral system. It favours: (1) less party control over drawing up candidate lists; (2) the elimination of gender and other quotas; (3) toughening up the law on political incompatibilities with public office; (4) tightening up control over public posts to stop parties receiving public funding. In the same vein, it seeks to slash the number of municipal and local representatives, and to limit the number of political advisors employed. Vox has raised the idea of appointing members of Spain's General Council of The Judiciary (CGPJ) and the Supreme Court (TS) on the basis of merit rather than on political affiliation. Further proposals are that the TS assume the functions of the Constitutional Court, and that trial by jury be abolished. 
These features place Vox firmly in the orbit of Europe's Far-Right parties, as its participation in the Koblenz Summit in January 2017 clearly revealed. Its political bedfellows at that summit were France's Front National, Germany's AfD, and Austria's Freedom Party [Freiheitliche Partei Österreichs - FPÖ]. The aim of the summit was for the three parties to co-ordinate their European strategy. Nevertheless, Vox is not fervently anti-EU or particularly Populist. Indeed, after the European elections, it joined the European Conservatives and Reformists (ECR) group, distancing itself from efforts by Steve Bannon to form a group of Far-Right, Eurosceptic parties under the baton of Marine Le Pen and Matteo Salvini (Barrio, in press).

Vox's position on the EU is ambivalent. Its foundational manifesto contains no references to Europe whatsoever, from which one can assume that the $\mathrm{EU}$ is not a key issue for the party. Its manifesto for the 2014 European Elections made vague noises about improving the workings of $\mathrm{EU}$ institutions and policies, and to make the EU more democratic. Indeed similar proposals have been on the EU's own wish list for decades without anything ever coming of them. From 2015 onwards, coinciding with The Refugee Crisis, Vox aligned itself with the positions taken by The Visegrad Group on immigration, and began to favour a more inter-governmental approach in the EU and being more explicit in rejecting supra-nationalism and any kind of non-State participation in EU decisions. That said, Vox does not question Spain's membership of the EU but rather seeks to change the organisation from within - a line taken by most Far-Right parties in the 2019 elections. In its manifesto for those elections, it stressed the sovereignty of States, their territorial integrity and the need to maintain Europe's JudaoChristian culture in the face of foreign threats, and to tighten up on immigration, political asylum, and on security and defence matters.

Even so, Vox lacks the Populist component usually found on the Far-Right. It is true that it lambasts the main parties and calls for democratic renewal and the need to carry out institutional reforms. Vox argues that such reforms are needed to stop the rot caused by the party system in general and by the wholesale corruption of Spain's two biggest parties in particular. Yet it does not meet all of the criteria of a Populist party as set out in the academic literature, and in particular those defined by Mudde (2004). Thus Vox neither thinks that there are two homogeneous groups - a virtuous People on the one hand and a vice-ridden elite on the other - nor does it assume an antagonistic relationship between them. Likewise, it does not see politics as the result of such an antagonistic relationship, nor does it show a preference for direct democracy versus the other instruments in Liberal Democracy's tool-box. It does not even suggest that sovereignty flows from The People but rather sees it as stemming from Spain. While Vox is not wholly free from Populism's reach - a trait shared by most parties in The West (especially those with a yen for political moralisation) - it is not Populist.

Vox is a singular case of a Far-Right party that is not a Populist one. This makes Spain an exception on the European scene. The 2008 political and economic crisis gave birth to the party but that does not explain its success. Rather, it was the political crisis sparked by the possibility of Catalonia's secession at the end of 2017 and the PP's credibility crisis in the Spring of 2018 that gave Vox wings. Vox is a Spanish nationalist party that lies on the Far Right and whose growth stems not from its Populism but rather than from its position in relation to the two main fault lines defining political life in Spain. Both fault lines played a key role in the last election cycle and - as in Spain's Second Republic (1934-1939) — tend to be super-imposed, magnifying the seismic forces reshaping the political landscape.

\section{FINAL CONSIDERATIONS}

In Spain, two factors combined that usually favour the emergence of Populism. They were the 2008 economic crisis and the 2014 political crisis. Yet Populism has not taken root in Spain, making the country a rare exception among Western Democracies.

Historically, Far-Right Populist parties have had very little impact in Spain and then only in the local tier 
of government. The reasons for this lie in: (a) the country's rejection of Franco's poisoned legacy; (b) the electorate's ideological moderation; (c) the hurdles in the electoral system to winning seats and get institutional representation; (d) PP hegemonic presence in which the party attracted voters who in another context might be labelled radical Populists. Until recently, all these factors presented a well-nigh insuperable barrier to Populist parties' wielding power.

The Populist parties that emerged in the various waves found it hard to take root given the near-monopoly of power exercised by the two main parties. Among the new parties emerging from the crisis, Podemos is one that calls itself Populist in keeping with Laclau's definition. Yet the party failed to get its approach adopted and ended up by fitting in with Spain's framework for political competition and battling it out with PSOE for pride of place on the Left of the political spectrum.

In any event, the presence of a strong national fault line made it hard for Podemos to foist its Populist notions on the country's diverse demoi. Ciudadanos, meanwhile, shared Populist criticism of the established parties and stressed its eagerness to foster democratic renewal. Yet it shares no other features that would allow us to label it as 'Populist'. Indeed, Ciudadanos has been forced to stress its position as a Liberal party in relation to the Left-Right fault line, and its opposition to peripheral nationalisms in relation to the centre-periphery fault line.
Finally, the emergence of Vox has shown that Spain is not wholly immune to the Far-Right, disproving a belief that was widely held until recently. Nevertheless, the party's rapid growth was fuelled by Catalonia's attempt to secede and the fragmentation of the Right and, with it, a greatly weakened PP. By contrast, Vox's rising star had little to do with the economic and political crises mentioned earlier. Vox shares various traits with other Far-Right parties: traditionalism; 'nativism'; rejection of Feminism. Yet it still lacks the Populist component. That is because the party does not have a dualistic vision of society ('We The People' versus 'them', the elites). Neither does it pass itself off as 'The Voice of The People' or prefer 'direct democracy' to parliamentary democracy. It is thus a rare example of a Far-Right party that is not a Populist one. Above everything, it stresses Spanish nationalism and the indivisible unity of Spain, revealing the primacy it gives to the traditional fault lines found in Spanish politics.

Despite the deep-seated changes undergone by Spain's system of parties of late, the Left-Right fault line and the national fault line have greatly hindered the birth and growth of Populism in the country. Both faults tend to work in a synergetic fashion, stopping Populism - as defined by Mudde (2004) — from taking hold. This is because the notion of a society split into two homogeneous, antagonist groups (namely, The People versus The Elites) has no traction in Spain and merely elicits voter indifference and incomprehension. Quite simply, there are issues dearer to Spaniards' hearts that shape the political battle lines.

\section{BIBLIOGRAPHIC REFERENCES}

Alonso, S. and Rovira Kaltwasser, C. (2015). Spain: No Country for the Populist Radical Right?, South European Society and Politics, 20(5), 21-45.

Álvarez Tardío, M. (2017). El populismo en la democracia española: De Gil a Podemos. In A. Rivero, J. Zarzalejos, J. and J. del Palacio (co-ord.), Geografía del Populismo (p. 260-271). Madrid: Tecnos.

Barrio, A. (2017a). El populismo y la excepcionalidad española. Quaderni di Diritto e Politica Ecclesiastica, 2, 263-276.

Barrio, A. (2017b). Ciutadans: De la irrelevancia a liderar la oposición. In J. Marcet and L. Medina (ed.), La política del proceso: Actores y elecciones (2010-2016) (p. 125-137). Barcelona: Institut de Ciències Polítiques i Socials. 
Barrio, A. (2017c). El partido anticatalanista que hizo las Españas. In E. Forti, A. González Vilata and E. Ucelay-Da Cal (ed.), El Proceso separatista en Cataluña: Análisis de un pasado reciente (2006-2017) (p. 225-243). Granada: Comares.

Barrio, A. (2019). "Vox, la fin de de l'exception espagnole" Fondation pour l'Innovation Politique (Fondapol).

Barrio, A. (in press). Vox y la irrupción de la derecha radical en España. In O. Barberà (ed.), La derecha radical. València: Fundació Nexe.

Barrio, A., Barberà, O. and Rodríguez-Teruel, J. (2018). Spain Steals from Us!' The 'Populist Drift' of Catalan Regionalism. Comparative European Politics, 16(6) 993-1011.

Bosch, A. and Durán, I. (2017). How Does Economic Crisis Impel Emerging Parties on the Road to Elections? The Case of the Spanish Podemos and Ciudadanos. Party Politics, 25(2), 257-267. DOI: 10.1177/1354068817710223

Casals, X. (1998). La tentación neofascista en España. Barcelona: Plaza \& Janés.

Casals, X. (2011). Cataluña: ¿Nuevos partidos para viejas inquietudes? In J. Marcet and X. Casals, Partidos y elecciones en la Cataluña del siglo XXI (p. 99-133). Barcelona: Institut de Ciències Polítiques i Socials.

Casals, X. (2013). El pueblo contra el parlamento. Barcelona: Pasado y Presente.

Canovan, M. (1982). Two Strategies for the Study of Populism. Political Studies, 30(4) 544-552.

Cordero, G. and Montero, J. R. (2015). Against Bipartyism, towards Dealignment? The 2014 European Election in Spain. South European Society and Politics, 20(3) 357-379.

Eatwell, R. and Goodwin, M. (2018). National Populism: The Revolt Against Liberal Democracy. London: Pelican Book.

Esteban, I. and Martín, I. (May 2017). Is There a Hidden Populist Right in Spain? Congress held at Univerzita Karlova (Prague, Czech Republic), Third Prague Populism Conference «Current Populism in Europe and the Role of the Media». Panel «Left and Right Populism in the Iberian Peninsula».

Hernández-Carr, A. (2011). ¿La hora del populismo? Elementos para comprender el «éxito» electoral de Plataforma per Catalunya. Revista de Estudios Políticos, (153) 47-74.

Hernández-Carr, A. (2012). La irrupción de la nueva extrema derecha en España: Un análisis de la trayectoria, estrategia política flybase electoral de Plataforma per Catalunya (PhD thesis). Universitat Autònoma de Barcelona, Bellaterra, Barcelona. Source http://www.tesisenred.net/handle/10803/96408

Ivaldi, G., Lanzone, M. E. and Woods, D. (2017). Varieties of Populism across a Left-Right Spectrum: The Case of the Front National, the Northern League, Podemos and Five Star Movement. Swiss Political Science Review, 23(4), 354-376

Kriesi, H. and Pappas, T. S. (2015). European Populism in the Shadow of the Great Recession. Colchester: European Consortium for Political Research.

Laclau, E. (2005). La razón populista. Mexico City: Fondo de Cultura Económica.

Mair, P. (2013). Ruling the Void. London: Verso.

Marzouki, N., McDonnel, D. and Rey, O. (ed) (2016). Saving the People. London: Hurst \& Co.

Medina, I. and Correa, P. (2016). The 2015 Spanish Election: The Times They Are a' Changing. Regional \& Federal Studies, 26(3), 407-417.

Moffit, B. and Tormey. S. (2014). Rethinking Populism: Politics, Mediatisation and Political Style. Political Studies, 62(2), 381- 397.

Mudde, C. (2004). The Populist Zeitgeist. Goverment and Opposition 39(4) 542-563.

Mudde, C. (2007). Populist Radical Right Parties in Europe. Cambridge: Cambridge University Press.

Mudde, C. and March, L. (2005). What's Left of the Radical Left? The European Radical Left Since 1989: Decline and Mutation. Comparative European Politics, 3(1), 29-49.

Norris, P. and Inglehart, R. (2018). Cultural Backlash and the Rise of Populism: Trump, Brexit and the Rise of Authoritarianism Populism. New York: Cambridge University Press.

Orriols, L. and Cordero, G. (2016). The Breakdown of the Spanish Two-party System: The Upsurge of Podemos and Ciudadanos in the 2015 General Election. South European Society and Politics, 21(4), 469492. DOI: $10.1080 / 13608746.2016 .1198454$

Pappas, T. S. (2014). Populist Democracies: Post-Authoritarian Greece and Post-Communist Hungary. Government and Opposition, 49(1), 1-23.

Pardos-Prado, S. (2012). The Electoral Effect of Immigration Preferences and the Centre-Periphery Cleavage in Spain. South European Society and Politics, 17(3), 503-518. 
Roberts, K. M. (2015). Populism, Political Mobilizations, and Crises of Political Representation. In C. de la Torre (ed.), The Promise and Perils of Populism: Global Perspectives (p. 140-158). Lexington: The University Press of Kentucky.

Rodon, T. and Hierro, M. J. (2016). Podemos and Ciudadanos Shake up the Spanish Party System: The 2015 Local and Regional Elections. South European Society and Politics, 21(3), 339-357.

Rodríguez-Teruel, J. and Barrio, A. (2016). Going National: Ciudadanos from Catalonia to Spain. South European Society and Politics, 21(4), 587-607.

Rodríguez-Teruel, J., Barrio, A. and Barberà, O. (2016). Fast and Furious: Podemos' Quest for Power in Multi-level Spain. South European Society and Politics, 21(4), 561-585.

Rodríguez-Teruel, J. and Barrio, A. (2018). El sistema de partidos multinivel en España. In J. M. Reniu (ed.), Sistema político español (p. 347-361). Barcelona: Huygens.

Solà, J. and Rendueles, C. (2017). Podemos, the Upheaval of Spanish Politics and the Challenge of Populism. Journal of Contemporary European Studies, 26(1), 99-116. DOI: 10.1080/14782804.2017.1304899

Rooduijn, M., Lang, S. L. and Van der Brug. W. (2012). A Populist Zeitgeist? Programatic Contagion by Populist Parties in Western Europe. Party Politics, 20(4), 563-575.

Sanders, K., Molina Hurtado, M. J. and Zoragastua, J. (2017). Populism and Exclusionary Narratives: The 'other' in Podemos 2014 European Union Election Campaign. European Journal of Communication, 32(6), $552-567$.

Shambaugh, J. C. (2012). The Euro's Three Crises. Brookings Papers on Economic Activity, 43(1), 157-231.

Stanley, B. (2008). The Thin Ideology of Populism. Journal of Political Ideologies, 13(1), 95-110.

Torreblanca, I. (2015). Asaltar los cielos. Barcelona: Debate.

Vallespín, F. and Martínez-Bascuñán, M. (2017). Populismos. Madrid: Alianza Editorial.

Zakaria, F. (1997). The Rise of Illiberal Democracy. Foreign Affairs, 76(6), 22-43.

Zarzalejos, J. (2017). Nacionalismo y populismo en España. In A. Rivero, J. Zarzalejos and J. del Palacio (co-ord.), Geografía del populismo. Madrid: Tecnos.

\section{BIOGRAPHICAL NOTE}

Astrid Barrio is Professor of Politics at Universitat de València (UV). She was awarded a PhD in Politics by Universitat Autònoma de Barcelona (UAE) and a DEA (Diplôme d'Études Approfondies — a first-year PhD diploma) by Institut d'Études Politiques de París (Sciences-Po). Her field of research covers parties, political elites, party systems, and nationalism. Astrid Barrio is the author of many books and has published papers in scholarly journals such as Ethnic and Racial Studies, Revista Española de Ciencia Política, Revista Española de Investigaciones Sociológicas, Comparative European Politics, South European Society and Politics, and Mediterranean Politics, among others. She regularly writes in newspapers such as El Periódico and La Vanguardia and is a frequent analyst on TV3, Catalunya Ràdio, La Ser, RAC1, and RTVE. She is the founder of Agenda Política and the magazine Política \& Prosa. Her entire academic output can be consulted at: https:// uv.academia.edu/AstridBarrio. 